\title{
Detection of transglutaminase activity using click chemistry
}

\author{
Remon van Geel • Marjoke F. Debets • \\ Dennis W. P. M. Löwik • Ger J. M. Pruijn • \\ Wilbert C. Boelens
}

Received: 21 November 2011 / Accepted: 1 December 2011/Published online: 17 December 2011

(C) The Author(s) 2011. This article is published with open access at Springerlink.com

\begin{abstract}
Transglutaminase 2 (TG2) is a $\mathrm{Ca}^{2+}$-dependent enzyme able to catalyze the formation of $\varepsilon(\gamma$-glutamyl)lysine crosslinks between polypeptides, resulting in high molecular mass multimers. We have developed a bioorthogonal chemical method for the labeling of TG2 glutamine-donor proteins. As amine-donor substrates we used a set of azide- and alkyne-containing primary alkylamines that allow, after being crosslinked to glutamine-donor proteins, specific labeling of these proteins via the azidealkyne cycloaddition. We demonstrate that these azide- and alkyne-functionalized TG2 substrates are cell permeable and suitable for specific labeling of TG2 glutamine-donor substrates in HeLa and Movas cells. Both the $\mathrm{Cu}(\mathrm{I})$-catalyzed and strain promoted azide-alkyne cycloaddition proved applicable for subsequent derivatization of the TG2 substrate proteins with the desired probe. This new method for labeling TG2 substrate proteins introduces flexibility in
\end{abstract}

Electronic supplementary material The online version of this article (doi:10.1007/s00726-011-1198-2) contains supplementary material, which is available to authorized users.

R. van Geel · G. J. M. Pruijn · W. C. Boelens Department of Biomolecular Chemistry, Nijmegen Centre for Molecular Life Sciences, Institute for Molecules and Materials and Netherlands Proteomics Centre, Radboud University, Nijmegen, The Netherlands

M. F. Debets · D. W. P. M. Löwik

Department of Bio-organic Chemistry, Institute for Molecules and Materials,

Radboud University, Nijmegen, The Netherlands

W. C. Boelens ( $\square)$

Department of Biomolecular Chemistry 271, Radboud University, PO Box 9101, 6500 HB Nijmegen, The Netherlands

e-mail: w.boelens@ncmls.ru.nl the detection and/or purification of crosslinked proteins, allowing differential labeling of cellular proteins.

Keywords Transglutaminase - Click chemistry · Azide . Alkyne $\cdot$ Cycloaddition $\cdot$ Protein modification

$\begin{array}{ll}\text { Abbreviations } \\ \text { BPA } & \text { 5-(Biotinamido)pentylamine } \\ \text { BCN } & \text { Bicyclo[6.1.0]nonyne } \\ \text { CuAAC } & \text { Copper(I)-catalyzed azide-alkyne cycloaddition } \\ \text { DIBAC } & \text { Azadibenzocyclooctyne } \\ \text { DIBO } & \text { Dibenzocyclooctyne } \\ \text { ESI } & \text { Electrospray ionization } \\ \text { HPLC } & \text { High-performance liquid chromatography } \\ \text { HspB6 } & \text { Heat shock protein B6 } \\ \text { IAM } & \text { Iodoacetamide } \\ \text { LRMS } & \text { Low-resolution mass spectrometry } \\ \text { SPAAC } & \text { Strain-promoted azide-alkyne cycloaddition } \\ \text { TG2 } & \text { Transglutaminase 2 }\end{array}$

\section{Introduction}

Transglutaminase 2 (TG2) catalyzes an acyl-transfer reaction between the $\gamma$-carboxamide functionality of a peptidylglutamine $(\mathrm{Q})$ and either the $\varepsilon$-amino functionality of a peptidyllysine $(\mathrm{K})$, leading to protein crosslinking, or a primary alkylamine such as putrescine, spermidine and spermine, leading to the formation of different monosubstituted $\gamma$-amides (Fesus and Piacentini 2002; Griffin et al. 2002; Lesort et al. 2000). Beside the crosslinking activity, TG2 also displays GTPase (Im et al. 1990), ATPase (Lai et al. 1998) and protein disulfide isomerase (Hasegawa et al. 2003) activity. The crosslinking activity of TG2 is a two-step reaction that is tightly regulated by calcium and GTP 
(Achyuthan and Greenberg 1987). The reaction starts with a nucleophilic attack by the thiol of the active-site cysteine on the $\gamma$-carboxamide of the amine-acceptor peptidylglutamine, leading to the formation of a thiolester intermediate and the release of ammonia. In the second step, the acyl group is transferred to the amine donor (Fesus and Piacentini 2002; Folk 1983). While TG2 is very restrictive toward the amine-acceptor glutamine residue, a wide variety of amine donors can be utilized (Esposito and Caputo 2005; Fesus and Piacentini 2002; Griffin et al. 2002). Under certain conditions, the amine can even be replaced by water and alcohols, leading to deamidation and esterification, respectively (Parameswaran et al. 1997; Samelak et al. 2010). The crosslinking activity of TG2 is involved in a wide variety of processes including apoptosis, cell motility, cell differentiation, formation, and remodeling of the extracellular matrix and wound healing (Fesus and Piacentini 2002; Griffin et al. 2002). Furthermore, posttranslational modifications introduced by TG2 have also been associated with various pathological conditions, such as deamidation of gluten peptides in celiac disease (Reif and Lerner 2004) and crosslinking, polyamination and deamidation of aggregated proteins in neurodegenerative diseases (Lesort et al. 2000).

To gain more insight in the role of TG2 catalyzed crosslinking in cellular and pathological processes, various methods for monitoring TG2 activity have been developed (Wilhelm et al. 1996; Nemes et al. 2005). Since TG2 is less restrictive towards the amine donor, these assays are often based on labeled primary alkylamine substrates such as dansylcadaverine and 5-(biotinamido)pentylamine (BPA), which can be detected via western blotting, ELISA, or immunocytochemistry. To further improve these detection methods, we developed a method based on the bioorthogonal chemical reporter strategy (Baskin and Bertozzi 2007; Sletten and Bertozzi 2009). In this approach, the amine donor is functionalized with a small chemical handle, which, after being incorporated in the amine-acceptor substrate protein by activated TG2, can be labeled via a bioorthogonal chemical ligation reaction. The advantage of this approach is that the introduced chemical handle is smaller than a conventional label, and therefore, may allow crosslinking to structurally less accessible amine-acceptor glutamine residues as well. In this way, amine-acceptor sites that exclusively allow incorporation of small (naturally occurring) polyamines may be revealed. Furthermore, the chemical ligation step increases the flexibility of the method, since the handle allows conjugation to a probe containing any desired label, enabling biotinylation, fluorescent labeling and covalent linkage to a solid support.

Only a few reactions, often collectively termed click chemistry (Kolb et al. 2001), have the characteristics required for efficient and specific labeling of tagged molecules in complex systems. These click reactions need to be fast, selective, high yielding and proceed in water. A prototypical click reaction is the $\mathrm{Cu}(\mathrm{I})$-catalyzed azide-alkyne cycloaddition (CuAAC), which is a triazole-forming reaction between an alkyne and an azide. (Rostovtsev et al. 2002; Tornoe et al. 2002). Over the last decade, this reaction has proven to be extremely well suitable for the labeling of posttranslationally modified biomolecules including protein glycosylation (Hsu et al. 2007), lipidation (Neef and Schultz 2009) and prenylation (DeGraw et al. 2010). Recently, $\mathrm{Cu}-$ AAC has been applied for the detection of the active form of TG2 using azide- or alkyne-containing inhibitors (Dafik and Khosla 2011). In order to circumvent the use of the toxic $\mathrm{Cu}(\mathrm{I})$ catalyst, which significantly reduced in vivo applicability, also highly strained cyclooctynes can be used for reactions with azides. (Baskin and Bertozzi 2007; Lutz 2008; Debets et al. 2010b). This strain-promoted azidealkyne cycloaddition (SPAAC) has been successfully applied to label biomolecules in living cells (Agard et al. 2004) or animals (Chang et al. 2010; Laughlin et al. 2008).

Here, we demonstrate that azide-functionalized aminedonor substrates are efficiently crosslinked by TG2 in living cells and that their subsequent labeling can be performed effectively via either CuAAC or SPAAC. Furthermore, we show that the azido group of the amine-donor substrate can be replaced by an alkynyl group allowing detection of the crosslinked product via conjugation with a labeled azide. With this two-step approach crosslinked TG2 substrates can be functionalized with one or more labels depending on the purpose of the experiment.

\section{Materials and methods}

Reagents and solvents were used as commercially provided, unless stated otherwise. Biotin-azide and Alexa ${ }_{555^{-}}$ azide were purchased from Invitrogen. The TG2 inhibitor Z006 was purchased from Zedira. NMR spectra were recorded on a Varian Inova $400\left(400 \mathrm{MHz}\right.$ for $\left.{ }^{1} \mathrm{H}\right)$ and a Bruker Avance III 500 (125 MHz for ${ }^{13} \mathrm{C}$ ). Chemical shifts $(\delta)$ are reported in $\mathrm{ppm}$ and coupling constants $(\mathrm{J})$ are reported in Hertz $(\mathrm{Hz})$. ESI-MS analyses were performed using a Thermo Scientific Advantage LCQ linear-ion trap (LRMS). HPLC was conducted on a Shimadzu system (DGU-20A5, LC-20AT, SIL-20A, CMB-20A and CTO20A) equipped with UV-Vis (SPD-20A) and evaporative light scattering detector (Alltech ELSD 200ES). For both LC-MS and HPLC analysis a Reprosil $100 \mathrm{C} 18,3 \mu \mathrm{m}$, $150 \mathrm{~mm} \times 3 \mathrm{~mm}$ analytical column (Screening Devices) was used and applied with the following mobile phase gradient profile: $0-5 \mathrm{~min} 5 \%$ acetonitrile/95\% water, 5-30 min gradient to $95 \%$ acetonitrile $/ 5 \%$ water, 30-40 $\min 95 \%$ acetonitrile/5\% water. The mobile phase was supplemented with $0.1 \%$ formic acid and 
trifluoroacetic acid for LC-MS and HPLC measurements, respectively. Infrared spectroscopy was performed on a Thermo Mattson Nicolet 300 FTIR. Thin layer chromatography (TLC) was carried out on Merck precoated silica gel 60 F-254 plates and the retardation factor $\left(R_{\mathrm{F}}\right)$ is reported where applicable. Column chromatography was performed using Merck silica gel 60 (0.015-0.040 mm). Fluorescent imaging of fixed cells was performed using the Leica-DMRA microscope equipped with COHU CCD camera and QFluoro 1.2 software. Cyclooctynes were synthesized as previously described (Debets et al. 2010a; Dommerholt et al. 2010; Ning et al. 2008). Expression and purification of recombinant rat HspB6 was performed as previously described (Boros et al. 2004).

\section{$N$-tert-Butoxycarbonyl(Boc)-pentane-1,5-diamine (5)}

1,5-Diaminopentane $(5.25 \mathrm{~g}, 51 \mathrm{mmol})$ was converted into the mono-protected $N$-Boc-pentane-1,5-diamine as previously described (Krapcho and Kuell 1990). Shortly, a solution of di-tert-butyl dicarbonate $(2.52 \mathrm{~g}, 12 \mathrm{mmol})$ in dioxane $(30 \mathrm{~mL})$ was added over a period of $2 \mathrm{~h}$ to a solution of 1,5-diaminopentane $(5.25 \mathrm{~g}, 51 \mathrm{mmol})$ in dioxane $(30 \mathrm{~mL})$ and stirred overnight at room temperature. The solvent was removed using a rotary evaporator and the residue was taken up in water $(50 \mathrm{~mL})$ and filtered. The filtrate was extracted with methylene chloride $(3 \times 50 \mathrm{~mL})$. The organic layers were combined, washed with water $(50 \mathrm{~mL})$, dried over $\mathrm{MgSO}_{4}$ and the solvent was removed using a rotary evaporator. $N$-Boc-pentane-1,5-diamine 5 was obtained as a brown yellowish oil $(2.05 \mathrm{~g}, 83 \%) ; R_{\mathrm{F}}=0.17$ (chloroform/ $\mathrm{MeOH} / \mathrm{H}_{2} \mathrm{O}$ 65:25:4); LRMS (ESI+, m/z) $[\mathrm{M}+\mathrm{H}]^{+}$calculated for $\mathrm{C}_{10} \mathrm{H}_{23} \mathrm{~N}_{2} \mathrm{O}_{2}$ : 203.2; found: 203.3.

Substrate 1 (5-azidopentan-1-amine hydrochloride)

The unprotected primary amine of $N$-Boc-pentane-1,5diamine 5 was converted into an azide using imidazole1-sulfonyl azide hydrochloride as diazotransfer reagent (Goddard-Borger and Stick 2007). Imidazole-1-sulfonyl azide hydrochloride $(1.00 \mathrm{~g}, 5 \mathrm{mmol})$ was added to $N$-Bocpentane-1,5-diamine $(0.67 \mathrm{~g}, 3.3 \mathrm{mmol}), \mathrm{K}_{2} \mathrm{CO}_{3}$, (0.76 g, $5.5 \mathrm{mmol})$ and $\mathrm{CuSO}_{4} \cdot 5 \mathrm{H}_{2} \mathrm{O}(25 \mathrm{mg}, 0.1 \mathrm{mmol})$ in $\mathrm{MeOH}$ $(50 \mathrm{~mL})$ and stirred overnight at room temperature. The solution was filtered and the solvent was removed using a rotary evaporator. The residue was taken up in $1 \mathrm{M} \mathrm{KHSO}_{4}$ $(75 \mathrm{~mL})$ and extracted with EtOAc $(3 \times 50 \mathrm{~mL})$. The organic layers were combined and the solvent was evaporated using a rotary evaporator. The residue was purified by column chromatography on silica gel (EtOAC/n-heptane $1: 3)$ to afford tert-butyl 5-azidopentylcarbamate as brown yellowish oil. A solution of the crude product in EtOAc $(5 \mathrm{~mL})$ was added dropwise to $2.3 \mathrm{M} \mathrm{HCl}$ in EtOAc
$(10 \mathrm{~mL})$ and stirred overnight at room temperature. The solvent was evaporated using a rotary evaporator and the residue was dissolved in $t$ - $\mathrm{BuOH}(20 \mathrm{~mL})$ followed by evaporation of the solvent, the latter was repeated once. The residue was lyophilized from water $(5 \mathrm{~mL})$ to give 5-azidopentan-1-amine hydrochloride $\mathbf{1}$ as an off-white solid $(257 \mathrm{mg}, 47 \%)$ with $\geq 99 \%$ purity according to ${ }^{1} \mathrm{H}$ NMR (Fig. S1A) and HPLC (Fig. S2) analysis; ${ }^{1} \mathrm{H}$ NMR $\left(400 \mathrm{MHz}, \mathrm{DMSO}_{-} \mathrm{d}_{6}\right) \delta 7.94(\mathrm{~s}, 3 \mathrm{H}), 3.29(\mathrm{t}, 2 \mathrm{H}$, $J=6.8 \mathrm{~Hz}), 2.71(\mathrm{se}, 2 \mathrm{H}, J=6.2 \mathrm{~Hz}), 1.51(\mathrm{~m}, 4 \mathrm{H}), 1.31$ (m, 2H); ${ }^{13} \mathrm{C}$ NMR (125 MHz, CD $\left.3 \mathrm{OD}\right) \delta 52.1,40.6,29.4$, 28.1, 24.7; FT-IR $v_{\max }$ film: 3412, 2933, 2090, 1606, 1502, 1467, 1282, 1256; LRMS (ESI+, m/z) $[\mathrm{M}+\mathrm{H}]^{+}$calculated for $\mathrm{C}_{5} \mathrm{H}_{13} \mathrm{~N}_{4}$ : 129.1 ; found: 129.1 .

\section{2-Azidoacetic acid (6)}

2-Chloroacetic acid (1.36 g, $14.4 \mathrm{mmol})$ was dissolved in water $(15 \mathrm{~mL})$ and cooled using an ice-bath. After adding $\mathrm{NaN}_{3}(4.00 \mathrm{~g}, 61.5 \mathrm{mmol})$ the mixture was allowed to warm to RT during a period of 16 hours. The mixture was acidified with concentrated $\mathrm{HCl}$ to $\mathrm{pH} 1$, while contact with the formed toxic hydrazoic acid was avoided, and extracted with EtOAc $(3 \times 50 \mathrm{~mL})$. The organic layers were combined, dried over $\mathrm{MgSO}_{4}$ and concentrated using a rotary evaporator. After co-evaporation with methylene chloride $(4 \times 50 \mathrm{~mL})$ the product was obtained as a slightly yellow liquid $(1.16 \mathrm{~g}, 80 \%) ; R_{\mathrm{F}}=0.59\left(\mathrm{AcOH} / \mathrm{MeOH} / \mathrm{CH}_{2} \mathrm{Cl}_{2}\right.$ 1:9:90); LRMS (ESI-, m/z) $[\mathrm{M}-\mathrm{H}]^{-}$calculated for $\mathrm{C}_{2} \mathrm{H}_{3} \mathrm{~N}_{3} \mathrm{O}_{2}$ : 100.0 ; found: 100.3 .

\section{6-Azidohexanoic acid (7)}

Imidazole-1-sulfonyl azide hydrochloride (2.50 g, $11.9 \mathrm{mmol})$ was added to 6-aminohexanoic acid $(1.33 \mathrm{~g}$, $10.1 \mathrm{mmol}), \mathrm{K}_{2} \mathrm{CO}_{3}(3.19 \mathrm{~g}, 23.1 \mathrm{mmol})$ and $\mathrm{CuSO}_{4} \cdot 5 \mathrm{H}_{2} \mathrm{O}$ (25 mg, $0.1 \mathrm{mmol})$ in $\mathrm{MeOH}(50 \mathrm{~mL})$ and stirred overnight at room temperature. The solution was filtered and the solvent was removed using a rotary evaporator. The residue was taken up in $1 \mathrm{M} \mathrm{KHSO}_{4}(75 \mathrm{~mL})$ and extracted with EtOAc $(3 \times 50 \mathrm{~mL})$. The organic layers were combined, dried over $\mathrm{MgSO}_{4}$ and the solvent was removed using a rotary evaporator. The product was obtained as a slightly yellow liquid $(1.52 \mathrm{~g}, 96 \%) ; R_{\mathrm{F}}=0.35$ (chloroform/MeOH/ $\mathrm{H}_{2} \mathrm{O}$ 65:25:4); LRMS (ESI-, m/z) $[\mathrm{M}-\mathrm{H}]^{-}$ calculated for $\mathrm{C}_{6} \mathrm{H}_{10} \mathrm{~N}_{3} \mathrm{O}_{2}$ : 156.1; found: 156.1 .

Substrate 2 ( $N$-(5-aminopentyl)-2-azidoacetamide hydrochloride)

Dicyclohexylcarbodiimide (DCC) (0.76 g, $3.7 \mathrm{mmol})$ was dissolved in EtOAc $(3.7 \mathrm{~mL})$ and added dropwise to a solution of $N$-Boc-pentane-1,5-diamine 5 (0.75 g, $3.7 \mathrm{mmol})$ 
and 2-azidoacetic acid $6(0.37 \mathrm{~g}, 3.7 \mathrm{mmol})$ in EtOAc $(50 \mathrm{~mL})$. The mixture was stirred overnight at room temperature and filtered. The filtrate was washed subsequently with $1 \mathrm{M} \mathrm{KHSO}_{4}(50 \mathrm{~mL})$, water $(50 \mathrm{~mL}), 5 \% \mathrm{NaHCO}_{3}$ $(50 \mathrm{~mL})$, water $(50 \mathrm{~mL})$ and brine $(50 \mathrm{~mL})$. The EtOAc layer was concentrated using a rotary evaporator yielding tert-butyl 5-(2-azidoacetamido)pentylcarbamate as a brown yellowish oil, which was further purified by column chromatography on silica gel (EtOAC/n-heptane 1:1). Tert-butyl 5-(2-azidoacetamido)pentylcarbamate dissolved in EtOAc $(5 \mathrm{~mL})$ was added dropwise to $2.3 \mathrm{M} \mathrm{HCl}$ in EtOAc $(10 \mathrm{~mL})$ and the mixture was stirred overnight at room temperature. The solvent was evaporated using a rotary evaporator and the residue was dissolved in $t-\mathrm{BuOH}$ $(20 \mathrm{~mL})$ followed by evaporation of the solvent, the latter was repeated once. The residue was dissolved in water (5 mL) and lyophilized to give $N$-(5-aminopentyl)-2-azidoacetamide hydrochloride $\mathbf{2}$ as a slightly yellow oil which solidified in time to yield an off-white solid (345 mg, 42\%) with $\geq 95 \%$ purity according to NMR (Fig. S1B) and HPLC (Fig. S2) analysis; ${ }^{1} \mathrm{H}$ NMR (400 MHz, DMSO-d $\left.{ }_{6}\right) \delta 8.14$ $(\mathrm{t}, 1 \mathrm{H}, J=5.4 \mathrm{~Hz}), 7.86(\mathrm{~s}, 3 \mathrm{H}), 3.76(\mathrm{~s}, 2 \mathrm{H}), 3.04(\mathrm{q}, 2 \mathrm{H}$, $J=6.5 \mathrm{~Hz}), 2.70(\mathrm{se}, 2 \mathrm{H}, J=6.6 \mathrm{~Hz}), 1.51(\mathrm{~m}, 2 \mathrm{H}), 1.38$ $(\mathrm{m}, 2 \mathrm{H}), 1.27(\mathrm{~m}, 2 \mathrm{H}) ;{ }^{13} \mathrm{C}$ NMR $\left(125 \mathrm{MHz}, \mathrm{CD}_{3} \mathrm{OD}\right) \delta$ 170.2, 53.0, 40.6, 40.0, 29.8, 28.1, 24.6; FT-IR $v_{\max }$ film: 3257, 2933, 2107, 1653, 1550, 1260; LRMS (ESI+, m/z) $[\mathrm{M}+\mathrm{H}]^{+}$calculated for $\mathrm{C}_{7} \mathrm{H}_{16} \mathrm{~N}_{5} \mathrm{O}$ : 186.1; found: 186.9 .

Substrate 3 ( $N$-(5-aminopentyl)-6-azidohexanamide hydrochloride)

$N$-(5-aminopentyl)-6-azidohexanamide hydrochloride $\mathbf{3}$ was synthesized according to the procedure described for $\mathrm{N}$-(5-aminopentyl)-2-azidoacetamide hydrochloride $\mathbf{2}$ with the use of 6-azidohexanoic acid 7 instead of 2-azidoacetic acid 6 and EtOAC/n-heptane 3:1 as eluent for column chromatography. The product was obtained as an off-white solid (298 mg, 29\%) with $\geq 99 \%$ purity according to NMR (Fig. S1C) and HPLC (Fig. S2) analysis; ${ }^{1} \mathrm{H}$ NMR (400 MHz, DMSO-d $\left._{6}\right) \delta 7.84(\mathrm{~s}, 3 \mathrm{H}), 7.76(\mathrm{t}, 1 \mathrm{H}, J=5.4), 3.26$ (t, $2 \mathrm{H}, J=6.9$ ), 2.97 (q, 2H, $J=6.5), 2.69$ (se, $2 \mathrm{H}$, $J=6.5 \mathrm{~Hz}), 2.01(\mathrm{t}, 2 \mathrm{H}, J=7.3 \mathrm{~Hz}), 1.48(\mathrm{~m}, 6 \mathrm{H}), 1.34$ (qu, $2 \mathrm{H}, J=7.0 \mathrm{~Hz}), 1.24(\mathrm{~m}, 4 \mathrm{H}) ;{ }^{13} \mathrm{C}$ NMR $(125 \mathrm{MHz}$, $\left.\mathrm{CD}_{3} \mathrm{OD}\right) \delta 176.5,52.3,40.6,40.3,36.5,29.6,29.5,28.1$, 27.3, 26.6, 24.7; FT-IR $v_{\max }$ film: 3265, 2928, 2094, 1632, 1554, 1256; LRMS (ESI+, m/z) $[\mathrm{M}+\mathrm{H}]^{+}$calculated for $\mathrm{C}_{11} \mathrm{H}_{24} \mathrm{~N}_{5} \mathrm{O}$ : 242.2; found: 242.3 .

Substrate 4 ( $N$-(5-aminopentyl)pent-4-ynamide hydrochloride)

$N$-(5-aminopentyl)pent-4-ynamide hydrochloride $\mathbf{4}$ was synthesized according to the procedure described for
$N$-(5-aminopentyl)-2-azidoacetamide hydrochloride 2 with $N$-Boc-pentane-1,5-diamine $5(0.97 \mathrm{~g}, 4.8 \mathrm{mmol})$ and the use of 4-pentynoic acid $(471 \mathrm{mg}, 4.8 \mathrm{mmol})$ instead of 2-azidoacetic acid 6. $\mathrm{MeOH} / \mathrm{CH}_{2} \mathrm{Cl}_{2}$ 1:9 was used as eluent for column chromatography. The product was obtained as an off-white solid (114 mg, 11\%) with $\geq 99 \%$ purity according to ${ }^{1} \mathrm{H}$ NMR (Fig. S1D) and HPLC (Fig. S2) analysis; ${ }^{1} \mathrm{H}$ NMR (400 MHz, DMSO-d $\left.\mathrm{d}_{6}\right) \delta 7.88(\mathrm{~m}, 4 \mathrm{H}), 2.98(\mathrm{q}, 2 \mathrm{H}$, $J=6.4), 2.71(\mathrm{~s}, 1 \mathrm{H}), 2.67$ (se, $2 \mathrm{H}, J=6.5 \mathrm{~Hz}), 2.30$ (m, $2 \mathrm{H}), 2.20(\mathrm{dt}, 2 \mathrm{H}, J=7.2$ and $1.6 \mathrm{~Hz}), 1.49(\mathrm{qu}, 2 \mathrm{H}$, $J=7.6 \mathrm{~Hz}), 1.34(\mathrm{qu}, 2 \mathrm{H}, J=7.9 \mathrm{~Hz}), 1.25(\mathrm{qu}, 2 \mathrm{H}$, $J=7.5 \mathrm{~Hz}) ;{ }^{13} \mathrm{C} \mathrm{NMR}\left(125 \mathrm{MHz}, \mathrm{CD}_{3} \mathrm{OD}\right) \delta 174.1,83.5$, 70.4, 40.6, 40.0, 36.0, 29.8, 28.1, 24.6, 15.8; FT-IR $v_{\text {max }}$ film: 3300, 2941, 1632, 1558; LRMS (ESI+, m/z) $[\mathrm{M}+\mathrm{H}]^{+}$calculated for $\mathrm{C}_{10} \mathrm{H}_{19} \mathrm{~N}_{2} \mathrm{O}$ : 183.2; found: 183.3.

\section{Biotin-alkyne (8)}

Propargylamine $(2.91 \mu \mathrm{L}, 66 \mu \mathrm{mol})$ was added to a solution of biotin-NHS (Sigma) $(25 \mathrm{mg}, 73 \mu \mathrm{mol})$ in DMSO $(659 \mu \mathrm{L})$ and the mixture was rotated overnight at room temperature. A solution of $2 \mathrm{M}$ Tris- $\mathrm{HCl}, \mathrm{pH} 7.5(300 \mu \mathrm{L})$ was added to block unreacted biotin-NHS and the mixture was rotated for 1 hour at room temperature. LRMS (ESI+, $\mathrm{m} / \mathrm{z})[\mathrm{M}+\mathrm{H}]^{+}$calculated for $\mathrm{C}_{13} \mathrm{H}_{20} \mathrm{~N}_{3} \mathrm{O}_{2} \mathrm{~S}$ : 282.1; found: 282.1 .

\section{Q-peptide (9)}

Biotin-GQEPVR was synthesized on solid support (Wang resin) using standard Fmoc-based peptide synthesis methods and commercially available Fmoc amino acids. LRMS $(\mathrm{ESI}+, \mathrm{m} / \mathrm{z})[\mathrm{M}+\mathrm{H}]^{+}$calculated for $\mathrm{C}_{38} \mathrm{H}_{63} \mathrm{~N}_{12} \mathrm{O}_{12} \mathrm{~S}$ : 911.5; found: 911.5 .

\section{K-peptide (10)}

Biotin-GNEPVK was synthesized analogously to 9. LRMS $(\mathrm{ESI}+, \mathrm{m} / \mathrm{z})[\mathrm{M}+\mathrm{H}]^{+}$calculated for $\mathrm{C}_{37} \mathrm{H}_{60} \mathrm{~N}_{10} \mathrm{O}_{12} \mathrm{~S}$ : 869.4; found: 869.5 .

Transglutaminase-catalyzed crosslinking of HspB6

Reactions were performed in a solution of $50 \mathrm{mM}$ Tris$\mathrm{HCl}, \mathrm{pH} \mathrm{7.5,} 150 \mathrm{mM} \mathrm{NaCl}, 20 \%$ glycerol and $5 \mathrm{mM}$ $\mathrm{CaCl}_{2}$. The crosslinking reactions of substrate 1-3 with the Q-peptide were performed in a total volume of $1,200 \mu \mathrm{L}$ containing $1 \mathrm{mM}$ Q-peptide, $1 \mathrm{mM}$ of the appropriate amine-donor substrate and $13 \mu \mathrm{g} / \mathrm{mL}$ gpTG2 $(\geq 1.5 \mathrm{U} / \mathrm{mg}$, Sigma). Reactions were incubated at $37^{\circ} \mathrm{C}$ and at the indicated time-points $190 \mu \mathrm{L}$ of each reaction was mixed with $10 \mu \mathrm{L} 0.5 \mathrm{M}$ EDTA and subjected to HPLC or LC/MS analysis. The crosslinking reactions with HspB6 
were performed in a total volume of $50 \mu \mathrm{L}$ containing $25 \mu \mathrm{M}$ HspB6, $250 \mu \mathrm{M}$ of the appropriate primary amine substrate and either no or $50 \mu \mathrm{g} / \mathrm{mL}$ gpTG2. Reactions were incubated for $2 \mathrm{~h}$ at $37^{\circ} \mathrm{C}$ followed by labeling with biotinylated probes and SDS-PAGE and western blot analysis (see below).

\section{Transfection}

TG2 specific siRNAs (TG2 siRNA1 and TG2 siRNA2) and a control siRNA (GFP siRNA) were purchased from Eurogentec. The sequences of TG siRNA1, TG2 siRNA2 and GFP siRNA are 5'-GCGUCGUGACCAACUAC AAdTdT-3', 5'-ACCUUCUCAUCGAGUACUUdTdT- $3^{\prime}$ and $5^{\prime}$-CCAUGUAACCGUAAGAAUAdTdT- $3^{\prime}$, respectively. pIRES-HspB6 construct has been described before (Boros et al. 2004). Approximately $24 \mathrm{~h}$ prior to siRNA or DNA transfection HeLa cells were plated in DMEM with $10 \%$ fetal calf serum in six-well plates. HeLa cells were transfected either with $20 \mu \mathrm{M}$ siRNA using Oligofectamine $^{\mathrm{TM}}$ reagent (Invitrogen), or with a total of $1 \mu \mathrm{g}$ of pIRES-HspB6 DNA per well using FuGENE6 ${ }^{\mathrm{TM}}$ (Roche), both in accordance with the manufacturer's instructions. HeLa cells were labeled with primary amine substrates approximately $24 \mathrm{~h}$ posttransfection (see below).

\section{Labeling of HeLa cells with primary amine substrates}

Approximately $3 \times 10^{5} \mathrm{HeLa}$ cells were plated in DMEM with $10 \%$ fetal calf serum in six-well plates. After $24 \mathrm{~h}$, HeLa cells were incubated as indicated with $250 \mu \mathrm{M}$ of the appropriate substrates, $10 \mu \mathrm{M}$ A23187 and/or $50 \mu \mathrm{M}$ Z006. After $2 \mathrm{~h}$, cells were harvested either by scraping or by removing the supernatant medium, incubating with $200 \mu \mathrm{L}$ Non-enzymatic Cell Dissociation Solution (Sigma) and recombining with the supernatant medium. Cells were washed twice with PBS and resuspended in ice-cold lysis buffer [25 mM Tris- $\mathrm{HCl}, \mathrm{pH} 7.5,150 \mathrm{mM} \mathrm{NaCl}, 1 \%$ NP40, Complete EDTA-free Protease Inhibitor Cocktail (Roche)]. Lysates were incubated on ice for $15 \mathrm{~min}$, sonicated $\left(5\right.$ times $30 \mathrm{~s}$ at $\left.0^{\circ} \mathrm{C}\right)$ and centrifuged at $13,000 \mathrm{rpm}$ for $10 \mathrm{~min}$ at $4^{\circ} \mathrm{C}$. Protein concentrations were determined using the Pierce BCA Protein assay (Thermo scientific). Lysates were used for immunoprecipitation or directly for labeling with biotinylated probes (see below).

\section{Immunoprecipitation}

For each immunoprecipitation, $2 \mu \mathrm{L}$ of rabbit polyclonal anti-HspB6 antibody was coupled to $10 \mu \mathrm{L}$ protein A-agarose beads (Kem-En-Tec Diagnostics) by rotating end-over-end for $1 \mathrm{~h}$ at $4^{\circ} \mathrm{C}$ in IPP500 $(500 \mathrm{mM} \mathrm{NaCl}$, $10 \mathrm{mM}$ Tris- $\mathrm{HCl}, \mathrm{pH} 8.0,0.05 \%$ NP40). Beads were washed trice with IPP500 and once with IPP150 (150 mM $\mathrm{NaCl}, 10 \mathrm{mM}$ Tris-HCl, pH 8.0, 0.05\% NP40). The lysate of (labeled) pIRES-HspB6 transfected HeLa cells was added to the beads and rotated end-over-end overnight at $4{ }^{\circ} \mathrm{C}$ in IP150. Beads were washed twice with IPP500 and once with PBS followed by labeling with biotinylated probes (see below).

\section{Labeling with biotinylated probes}

The labeling reactions were performed in PBS containing $0.1 \mathrm{mM}$ of the appropriate biotinylated probe (terminal alkyne, DIBO, DIBAC, BCN or azide) and either $10 \mu \mathrm{g}$ cell lysate proteins, $1 \mu \mathrm{g}$ (TG2 treated) HspB6 or $10 \mu \mathrm{L}$ beads containing the immunoprecipitated proteins. The reactions in solution were performed in a final volume of $15 \mu \mathrm{L}$ and the reactions on the beads in $100 \mu \mathrm{L}$. When applying SPAAC, the lysate proteins were pre-incubated for $30 \mathrm{~min}$ with $1 \mathrm{mM}$ Iodoacetamide (IAM) to reduce azide-independent labeling (Van Geel et al., unpublished data). For $\mathrm{Cu}(\mathrm{I})$ dependent cycloadditions $10 \times$ concentrated freshly prepared working solution was added, containing $10 \mathrm{mM}$ $\mathrm{CuSO}_{4}, 10 \mathrm{mM}$ sodium ascorbate and $10 \mathrm{mM}$ tris(1-((O-ethyl) carboxymethyl)-(1,2,3-triazole-4-yl))methylamine (triazole ligand). All reaction mixtures were incubated at $4^{\circ} \mathrm{C}$ for $1 \mathrm{~h}$, after which the beads were washed once with PBS. Sample buffer was subsequently added to a final concentration of $2 \%$ SDS, $5 \% \beta$-mercaptoethanol, $10 \%$ glycerol, $0.03 \%$ bromophenol blue and $0.25 \mathrm{M}$ Tris-HCl, $\mathrm{pH} 6.8$ and incubated for $5 \mathrm{~min}$ at $95^{\circ} \mathrm{C}$. Samples were analyzed by SDS-PAGE and western blot (see below).

\section{SDS-PAGE and western blot analysis}

Sodium dodecyl sulphate polyacrylamide gel electrophoresis (SDS-PAGE) was performed according to standard procedures. Proteins were transferred to nitrocellulose membranes (GE Healthcare) by electroblotting for western blot analysis. The membranes were incubated with primary antibodies (rabbit polyclonal anti-HspB6, mouse monoclonal anti- $\gamma$-tubulin (GTU-88, Abcam) and mouse monoclonal anti-TG2 (CUB $7402+$ TG100, Neomarkers)) or with IRDye 800CW Streptavidin (Li-Cor) to detect biotinylated proteins. Bound antibodies were detected by incubation with IRDye $680 \mathrm{CW}$-conjugated polyclonal goat anti-mouse or goat anti-rabbit antibodies (Li-Cor) and visualized using an Odyssey Infrared Imaging System (Li-Cor).

Fluorescent imaging

Approximately $24 \mathrm{~h}$ prior to the labeling $1 \times 10^{5}$ Movas cells (ATCC CRL-2797) were plated in DMEM supplemented with $10 \%$ fetal calf serum in 24-well plates with 
$12 \mathrm{~mm}$ round glass coverslips. The cells were incubated with or without $250 \mu \mathrm{M}$ substrate 4 and $50 \mu \mathrm{M}$ FITCcadaverine for $24 \mathrm{~h}$. The cells were rinsed twice with PBS and incubated for $15 \mathrm{~min}$ in DMEM with $10 \%$ fetal calf serum, allowing diffusion of non-crosslinked substrates, which otherwise cause background labeling (Lajemi et al. 1997), into the medium. The cells were rinsed twice with PBS, fixed with $2 \%$ paraformaldehyde solution for $10 \mathrm{~min}$, and rinsed twice with PBS. For each coverslip, $100 \mu \mathrm{L}$ PBS containing $1 \mathrm{mM} \mathrm{CuSO}$, $1 \mathrm{mM} \mathrm{NaAsc,} 1 \mathrm{mM}$ triazole ligand and $25 \mu \mathrm{M}$ Alexa 555 -Azide was pipetted on parafilm in a humidified incubation chamber. The coverslips were inverted, placed on top of this solution and incubated for $1 \mathrm{~h}$ at room temperature. Coverslips were transferred to a 24-well plate and washed 4 times with PBS and once with water. Coverslips were agitated for $3 \mathrm{~min}$ between washes. Coverslips were dried, mounted on slides using Mowiol 4-88 mounting medium containing $0.02 \%$ of $\mathrm{NaN}_{3}$ and imaged by fluorescence microscopy.

\section{Results and discussion}

Azido substrates and biotinylated alkynyl probes

We have synthesized three azide-functionalized aminedonor substrates for TG2 (Fig. 1a). All three substrates contain a pentylamine that mimics the $\varepsilon$-amino group of a peptidyllysine, which is essential for effective recognition by TG2 (Alea et al. 2009; Jeon et al. 2003). Substrate 1 is the smallest TG2 substrate, in which the azide is directly conjugated to the pentylamine. In substrates $\mathbf{2}$ and $\mathbf{3}$, a linker region is included consisting of an amide bond, which in substrate $\mathbf{3}$ is extended with a small hydrophobic alkyl chain. For the detection of the azide-functionality of substrates 1-3 after their incorporation into TG2 substrate proteins a panel of different alkynyl probes are available, consisting of one terminal alkyne and three strained cyclooctynes, i.e. dibenzocyclooctyne (DIBO) (Ning et al. 2008), azadibenzocyclooctyne (DIBAC) (Debets et al. 2010a) and bicyclo[6.1.0]nonyne (BCN) (Dommerholt et al. 2010) (Fig. 1b). To allow comparison with the labeling via BPA (Fig. 1a), which has previously been demonstrated to be a good TG2 substrate (Jeon et al. 2003), these alkynes were all biotin-conjugated, as depicted in Fig. 1b.

TG2-catalyzed crosslinking of azide-functionalized amine-donor substrates

To investigate whether the amine-donor substrates $\mathbf{1 - 3}$ can be crosslinked by TG2 to an amine-acceptor substrate, a synthetic Q-containing peptide (biotin-GQEPVR, $1 \mathrm{mM}$ ) was incubated with substrates $\mathbf{1}, \mathbf{2}$ or $\mathbf{3}(1 \mathrm{mM})$ in the
Fig. 1 Structures of TG2 substrates and biotinylated alkynes used in this study. a Biotinylated and azidefunctionalized TG2 aminedonor substrates. b Biotinylated terminal and ring-strained alkynes<smiles>NCCCCCNC(=O)CCCCC1SC[C@@H]2NC(=O)N[C@H]12</smiles>

5-(biotinamido)pentylamine

(BPA)<smiles>[R][C@H](CCCN)NC(=O)CN</smiles><smiles>[B]C1N[C@@H]2C(CCCCC(=O)NCC#C)SC[C@@H]2N1</smiles><smiles>[R]C(=O)NCCOCCNC(=O)CCCC[C@H]1SC[C@@H]2NC(=O)N[C@@H]21</smiles>

biotin-alkyne<smiles>[R]O[R16]=O</smiles>

DIBAC, $R=$<smiles>CCCCC(=O)N1Cc2ccccc2C#Cc2ccccc21</smiles>
$\mathrm{BCN}, \mathrm{R}=$<smiles>COC[C@H]1[C@H]2CCC#CCC[C@H]21</smiles> 


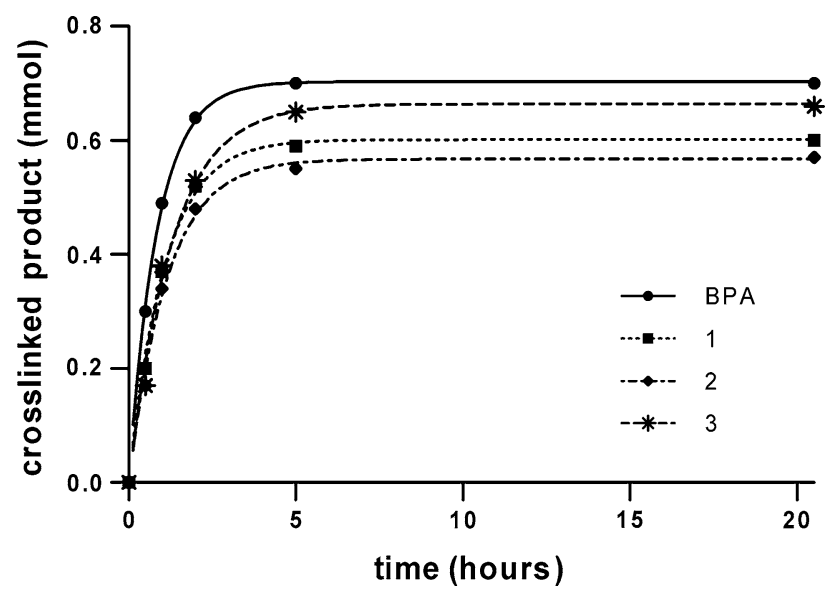

Fig. 2 Analysis of TG2-catalyzed crosslinking of azide-functionalized amine-donor substrates. Substrate 1, 2, 3 and BPA (1 mM) were incubated with the amine-acceptor peptide biotin-GQEPVR (1 mM) after which the amount of $\gamma$-glutamyl-monoamine crosslink product was monitored by HPLC and plotted versus time

presence of TG2. As a positive control, BPA was used. Crosslinking reactions were followed in time by analyzing small aliquots with HPLC, revealing the formation of a single reaction product for each amine-donor substrate. The amount of which was plotted versus reaction time (Fig. 2). For substrate 2, MS analysis confirmed that the mass of the product corresponds to the expected $\gamma$-glutamyl-monoamine crosslink product (Fig. S3), proving that substrate 2 is indeed recognized as amine-donor substrate by TG2. The crosslinking of substrates $\mathbf{1}, \mathbf{2}$ and $\mathbf{3}$ to the Q-peptide followed a similar time-course, showing that the way the azido group is linked to the pentylamine has no major influence on the substrate behavior of the molecules. Moreover, the crosslinking efficiencies are comparable to $\mathrm{BPA}$, indicating that $\mathrm{TG} 2$ recognizes these substrates equally well as BPA.

Detection of TG2-catalyzed crosslinking of heat shock protein B6 (HspB6/Hsp20)

In order to evaluate whether substrates 1-3, after being crosslinked by TG2, can be labeled via CuAAC we used HspB6 as a model system. HspB6 is an excellent aminedonor and acceptor substrate for TG2 (Boros et al. 2004, 2006) and its CuAAC-mediated biotinylation can easily be visualized via SDS-PAGE followed by western blot analysis. TG2-catalyzed crosslinking was performed by incubating substrate $\mathbf{1}, \mathbf{2}, \mathbf{3}$ or BPA $(250 \mu \mathrm{M})$ with HspB6 $(25 \mu \mathrm{M})$ for $2 \mathrm{~h}$ at $37^{\circ} \mathrm{C}$ in the presence or absence of active TG2. After the crosslinking reaction, the incorporated azide-handles were biotinylated via the CuAAC by incubating the (crosslinked) HspB6 $(1.7 \mu \mathrm{M})$ with biotinalkyne $(0.1 \mathrm{mM})$ for $1 \mathrm{~h}$ at $4^{\circ} \mathrm{C}$ in the presence of $\mathrm{CuSO}_{4}$, sodium ascorbate and triazole ligand (1 mM each). Reaction products were separated by SDS-PAGE followed by western blotting to detect all isoforms of HspB6 (Fig. 3a, lower panel) and the biotin-conjugated isoforms (Fig. 3a, upper panel). HspB6 contains both amine-donor and acceptor sites allowing the TG2-catalyzed formation of an intramolecular and a variety of intermolecular crosslinked products (Boros et al. 2004, 2006). Labeling of the HspB6 isoforms via the CuAAC is observed only when substrate $\mathbf{1}, \mathbf{2}$ or $\mathbf{3}$ was present during the crosslinking reaction (Fig. 3a, upper panel lanes 6, 8, 10). Furthermore, labeling is completely eliminated when TG2 was omitted (Fig. 3a, upper panel lanes 5, 7, 9). The labeled monomeric HspB6 appeared to migrate slightly slower than the unlabeled monomer (Fig. 3a, lower panel compare e.g. lane 5 and 6), which is likely due to the mass increase resulting from the substrate together with the biotinylated probe. The intensity of labeling observed for substrate 1-3 is comparable to that of BPA (Fig. 3a, upper panel compare lanes 6, 8 and 10 with lane 12), indicating that these substrates are crosslinked with similar efficiencies and that a (nearly) complete conversion of the introduced azides was achieved during the CuAAC. These results show that TG2 is able to crosslink the azide-containing substrates to HspB6 and that the introduced azide-moieties can be efficiently converted into the corresponding biotinylated triazole derivatives via CuAAC.

To evaluate labeling via SPAAC, the probes DIBO, DIBAC and BCN were used to label the crosslinked substrate 2. Therefore, HspB6 crosslinked to substrate 2 was incubated with the biotinylated derivatives of DIBO, DIBAC or BCN $(0.1 \mathrm{mM})$ for $1 \mathrm{~h}$ at $4^{\circ} \mathrm{C}$. Labeling via CuAAC and crosslinking with BPA, both performed as described above, were included as a control. Reactions were separated by SDS-PAGE and analyzed by western blotting for the HspB6 isoforms and biotinylated forms (Fig. 3b). All cyclooctynes showed efficient labeling, which was comparable to the labeling with the terminal alkyne and BPA (Fig. 3b, compare lanes 10, 14 and 18 with lanes 6 and 20). This implicates that under these conditions SPAAC results in a (nearly) complete conjugation of the cyclooctynes to the crosslinked substrate $\mathbf{2}$. Labeling via SPAAC was also highly specific, since hardly any labeling was observed when TG2 and/or substrate 2 was omitted (Fig. 3b, upper panel lanes 7-9, 11-13, 15-17). Only DIBAC and BCN showed weak azide-independent labeling of monomeric HspB6 (Fig. 3b, upper panel lanes 11, 13, 15 and 17). This azide-independent labeling is mainly caused by mild reactivity of the cyclooctynes towards the thiol of the reduced peptidylcysteine present in HspB6, which can be avoided by pre-incubating the (crosslinked) HspB6 with iodoacetamide (IAM) (Van Geel et al. unpublished data). 
A

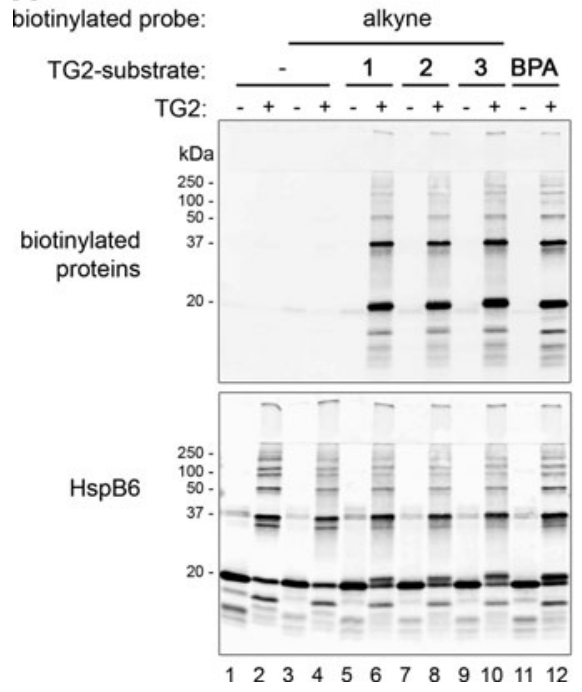

Fig. 3 Detection of TG2-catalyzed crosslinking of HspB6 via CuAAC and SPAAC. a Substrates 1, 2 and $\mathbf{3}$ were crosslinked by TG2 onto HspB6 and subsequently biotinylated via CuAAC using biotin-alkyne. b Substrate 2 was crosslinked by TG2 onto HspB6 and subsequently biotinylated via $\mathrm{CuAAC}$, using biotin-alkyne, and SPAAC, using DIBO, DIBAC and BCN. As negative controls, TG2, the azide-containing substrate and/or biotin-alkyne were omitted. The biotinylated TG2 substrate BPA was used as a positive

\section{Detection of crosslinked substrates in HeLa cells}

The efficiency by which the azide-containing substrates can be crosslinked by TG2 in vivo was determined by using HeLa cell cultures. The cells were incubated for $2 \mathrm{~h}$ with substrate $\mathbf{1}, \mathbf{2}, \mathbf{3}$ or BPA $(250 \mu \mathrm{M})$. The endogenous HeLa cell TG2 was activated through elevating intracellular $\mathrm{Ca}^{2+}$ levels either by harvesting the cells with a cell scraper, leading to a short elevation due to membrane damage (McNeil and Kirchhausen 2005), or by incubating with $\mathrm{Ca}^{2+}$-ionophore A23187 for $2 \mathrm{~h}$, leading to a continuous elevation. Lysates were prepared and the introduced azidehandles were biotinylated via $\mathrm{CuAAC}$ by incubating the lysate proteins $(10 \mu \mathrm{g})$ with biotin-alkyne $(0.1 \mathrm{mM})$ for $1 \mathrm{~h}$ at $4^{\circ} \mathrm{C}$. As a negative control, the CuAAC was also applied to lysates derived from cells without substrate incubation. Lysates were separated by SDS-PAGE followed by western blot analysis for biotinylated proteins. $\gamma$-Tubulin was used as a loading control (Fig. 4a). A clear labeling of proteins was observed when HeLa cells were treated with ionophore in the presence of substrate 1, 2, 3 or BPA (Fig. 4a, lanes 9, $12,15,18)$, indicating that the substrates, as BPA, are incorporated into a wide range of proteins upon ionophoretreatment, and that the CuAAC can be applied for biotinylation of the introduced azide-moieties in cell lysate proteins. However, the terminal alkyne also reacted mildly with cellular proteins in an azide-independent manner (Fig. 4a, lanes 4-6). This background staining was also
B

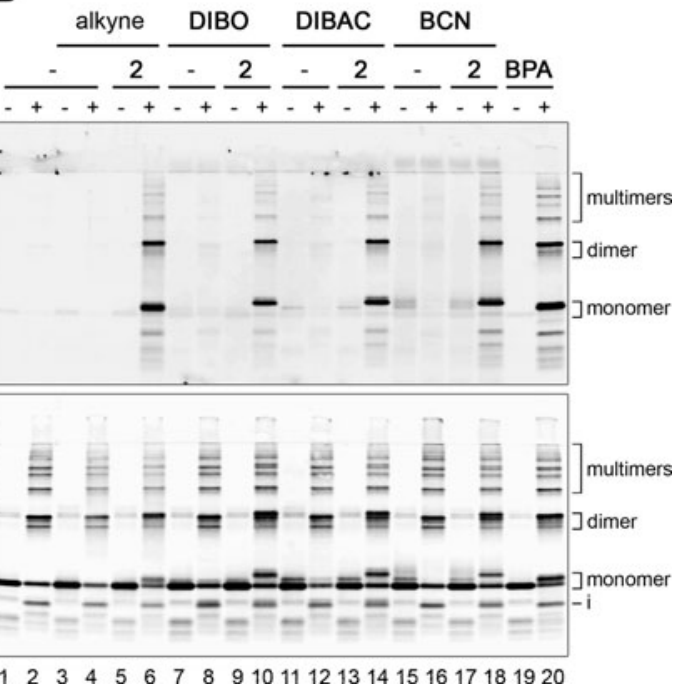

control for TG2 activity. HspB6 isoforms were separated by SDSPAGE and analyzed by western blotting using either labeled streptavidin to detect biotinylated proteins (upper panels) or antibodies directed to HspB6 (lower panels). The positions of HspB6 monomers, dimers and multimers are indicated on the right. Intramolecular crosslinked HspB6 monomers are indicated with $i$. The size and position of the protein markers are indicated on the left

encountered by other investigators in reactions where the alkyne is used as the probe (DeGraw et al. 2010; Speers and Cravatt 2004). The azide-independent labeling could not be prevented by preincubation with IAM, indicating that it is not caused by a reaction with reduced cysteines. Also different concentrations for the alkyne, ligand, reducing agent and copper(I)-source, did not reduce this azide-independent labeling (data not shown) (Hong et al. 2009). The background staining limits the sensitivity of the assay, as exemplified by the hardly detectable mild TG2 activity induced by scraping (Fig. 4a, compare lane 7 and 8, 10 and 11, 13 and 14, 16 and 17). This means that in a cell lysate efficient but not completely specific labeling of azidemodified proteins can be achieved via the CuAAC, allowing only sufficiently strong signals to be detected.

Next, it was determined whether azide-modified TG2substrate proteins in a cell lysate could be biotinylated using SPAAC. First, lysates were prepared of HeLa cells which were labeled with substrate $\mathbf{2}$ or BPA as described above. Prior to biotinylation via SPAAC, lysates were preincubated with IAM $(1 \mathrm{mM})$ for $30 \mathrm{~min}$ at room temperature to reduce azide-independent labeling by strained alkynes (Van Geel et al. unpublished data). Note that in contrast to CuAAC, the strained probes used for SPAAC did lead to IAM-sensitive background signals. The lysates were incubated with the biotinylated derivatives of the terminal alkyne, DIBO, DIBAC or BCN $(0.1 \mathrm{mM})$ for $1 \mathrm{~h}$ at $4^{\circ} \mathrm{C}$. After separation by SDS-PAGE, the biotinylated 
A

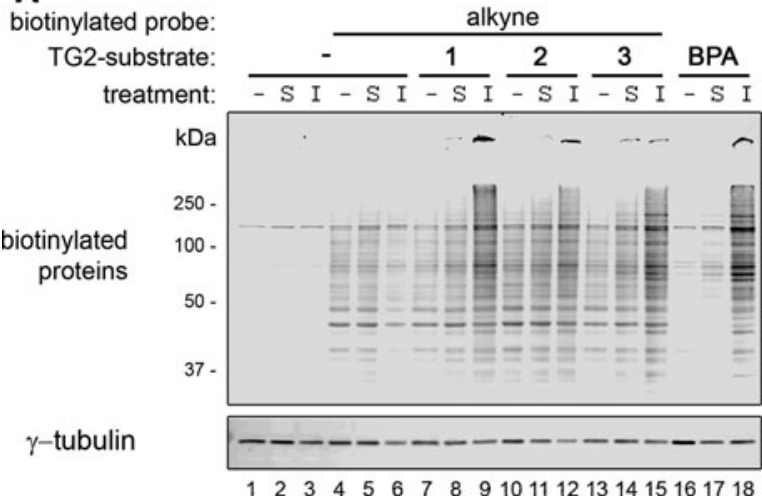

Fig. 4 Detection of TG2 substrate proteins in HeLa cells. a HeLa cells were cultured for $2 \mathrm{~h}$ without (-) or with substrate $\mathbf{1}, \mathbf{2}$, or $\mathbf{3}$ after which the lysates were labeled via CuAAC using biotin-alkyne. b HeLa cells were cultured for $2 \mathrm{~h}$ without (-) or with substrate $\mathbf{2}$ and subsequently biotinylated via $\mathrm{CuAAC}$, using biotin-alkyne, and SPAAC, using DIBO, DIBAC or BCN. TG2 was either not activated $(-)$, mildly activated through harvesting by scraping (S) or strongly

proteins were analyzed by western blotting. As a loading control $\gamma$-tubulin was visualized (Fig. 4b). In this experiment, the labeling with substrate 2 was more efficient than in the previous one (Fig. 4, compare lanes 10-12 in panel a with 7-9 in panel b). The reason for this variation in TG2 activation is not clear, but might be due to a variation in the condition of the HeLa cells. All strained alkynes showed highly efficient labeling comparable to the terminal alkyne and BPA (Fig. 4b, compare lanes 15, 21 and 27 with lanes 9 and 30). Only a low level of azide-independent labeling was observed which is in the same range as for CuAAC (Fig. 4b, compare lanes 10-12, 16-18 and 22-24 with lanes 4-6). These data show that in a cell lysate labeling of azide-modified proteins can be achieved via SPAAC with a similar efficiency and specificity as with CuAAC.

\section{Specificity of TG2 activity detection}

To confirm that TG2 is indeed responsible for the crosslinking of the azide-containing substrates 1-3 in HeLa cells, TG2 was either inhibited using the specific irreversible active-site inhibitor Z006, which is based on a 6-diazo5-oxo-norleucine reactive group (Verhaar et al. 2011; Schaertl et al. 2010), or downregulated using siRNAs directed against the TG2 mRNA. HeLa cells were incubated with Z006 for $2 \mathrm{~h}$ simultaneously with the azide-containing substrate. The siRNA transfections were performed 1 day prior to the substrate labeling using two different siRNAs directed against TG2 and one control siRNA directed against the green fluorescent protein (GFP). The labeling experiment was performed as described above using substrate $\mathbf{2}$ and CuAAC. Lysates were separated by SDS-PAGE and analyzed by western blotting for biotinylated proteins,
B

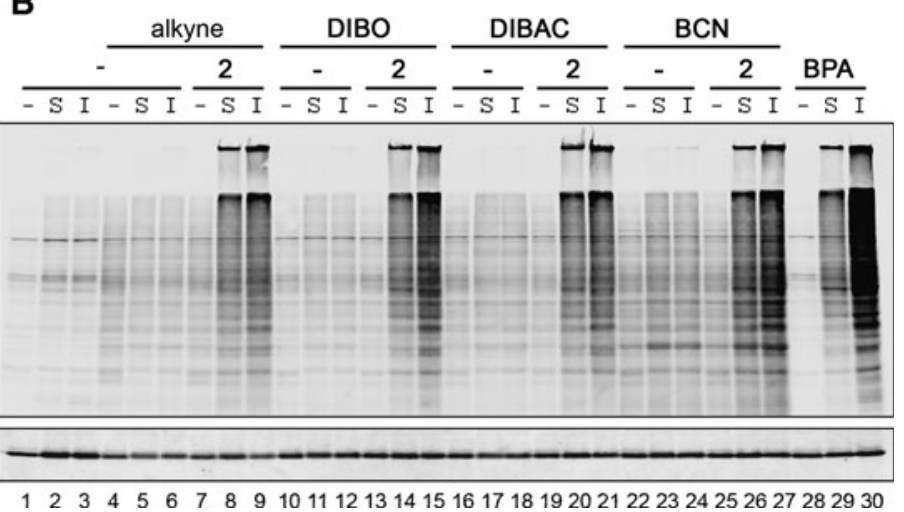

activated through incubating with $\mathrm{Ca}^{2+}$-ionophore A23187 (I). The biotinylated TG2 substrate BPA was used as a positive control for TG2 activity. Protein biotinylation was monitored by western blotting using labeled streptavidin (upper panels). As a loading control $\gamma$-tubulin was used (lower panels). The size and position of the protein markers are indicated on the left

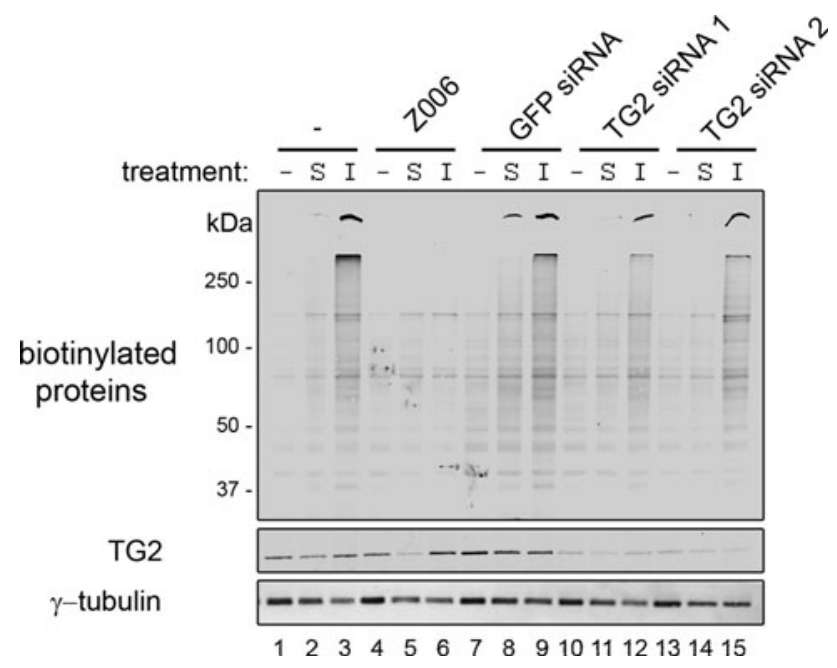

Fig. 5 TG2-dependency of substrate crosslinking. HeLa cells were transfected with siRNAs directed against TG2 (TG2 siRNA 1 or 2) or GFP (negative control) and, after 1 day, incubated with substrate 2 . In addition, untransfected cells were incubated without (-) or with TG2 inhibitor Z006 during the incubation with substrate 2 . The proteins crosslinked with the substrate were labeled with biotin-alkyne and analyzed by western blotting using labeled streptavidin to detect biotinylated proteins (upper panel) or antibodies directed against TG2 (middle panel) or $\gamma$-tubulin (lower panel). The size and position of the protein markers are indicated on the left

TG2 and $\gamma$-tubulin (Fig. 5). When substrate 2 was applied in the presence of Z006, ionophore-induced labeling was completely abolished (Fig. 5, compare lanes 3 and 6). Furthermore, ionophore-induced labeling was reduced in cells transfected with the TG2 siRNAs compared to cells transfected with the control siRNA (Fig. 5, compare lanes 12 and 15 with lane 9) due to a partial downregulation of TG2. These results indicate that the labeling of HeLa cell proteins 
with substrate $\mathbf{2}$ is indeed TG2-mediated. Since all azidefunctionalized substrates show similar biotinylated protein patterns (Fig. 4a), it is likely that the labeling with substrate $\mathbf{1}$ and $\mathbf{3}$ is also dependent on TG2.

Labeling with an alkyne-functionalized amine-donor substrate

Next, we tested if TG2 can also crosslink an alkyne-containing substrate. The advantage of such a substrate is that the labeling step with an azide- instead of alkyne-containing probe may produce less background staining when performing CuAAC in a cell lysate (DeGraw et al. 2010; Speers and Cravatt 2004). For this reason, the alkynecontaining substrate $\mathbf{4}$ was synthesized, which can be labeled with a biotinylated azide (Fig. 6a). Its CuAACbased labeling was compared with the azide-containing substrate $\mathbf{2}$, which is structurally most closely related. The substrates were crosslinked to HspB6 by TG2 and subsequently labeled via CuAAC (Fig. 6b). Substrate 2 again showed highly specific and efficient labeling comparable to BPA. Labeling via the alkyne-containing substrate 4 was also highly specific, but slightly less efficient (Fig. 6b, compare lane 10 with lane 6 and 12). Prolonged incubation with biotin-azide did not increase the labeling efficiency (data not shown), indicating that substrate $\mathbf{4}$ is a good TG2 substrate, but gives somewhat less efficient labeling.

Next, we compared the labeling of substrate $\mathbf{2}, \mathbf{4}$ and BPA in HeLa cells followed by biotinylation of the introduced azides or alkynes via CuAAC (Fig. 6c). In line with previous experiments, crosslinking of substrate 2 to cellular proteins followed by biotinylation via the CuAAC is highly efficient, but not completely specific due to azide-independent labeling of the terminal alkyne. When the alkyne-containing substrate $\mathbf{4}$ is crosslinked followed by biotinylation via the $\mathrm{CuAAC}$, protein labeling is less intense (Fig. 6c, compare lane 15 with lane 9 and 18), however, the biotinylated azide shows a much lower background labeling (Fig. 6c, lanes 10-12). As a result, the signal-to-noise ratio, based on the ionophore results (Fig. 6c, lanes 6, 9, 12, 15), was approximately 1.5 times higher with the alkyne-bearing substrate 4 than with the azide-bearing substrate $\mathbf{2}$. This means that in case the background is relatively high a better signalto-noise ratio might be obtained using an azide-containing probe instead of an alkyne-containing probe for the labeling step. These results are in good agreement with earlier reports (DeGraw et al. 2010; Speers and Cravatt 2004).

Cell permeability of azide- and alkyne-functionalized TG2 substrates

TG2 has been reported to be localized both in the intracellular and in the extracellular space (Park et al. 2010).
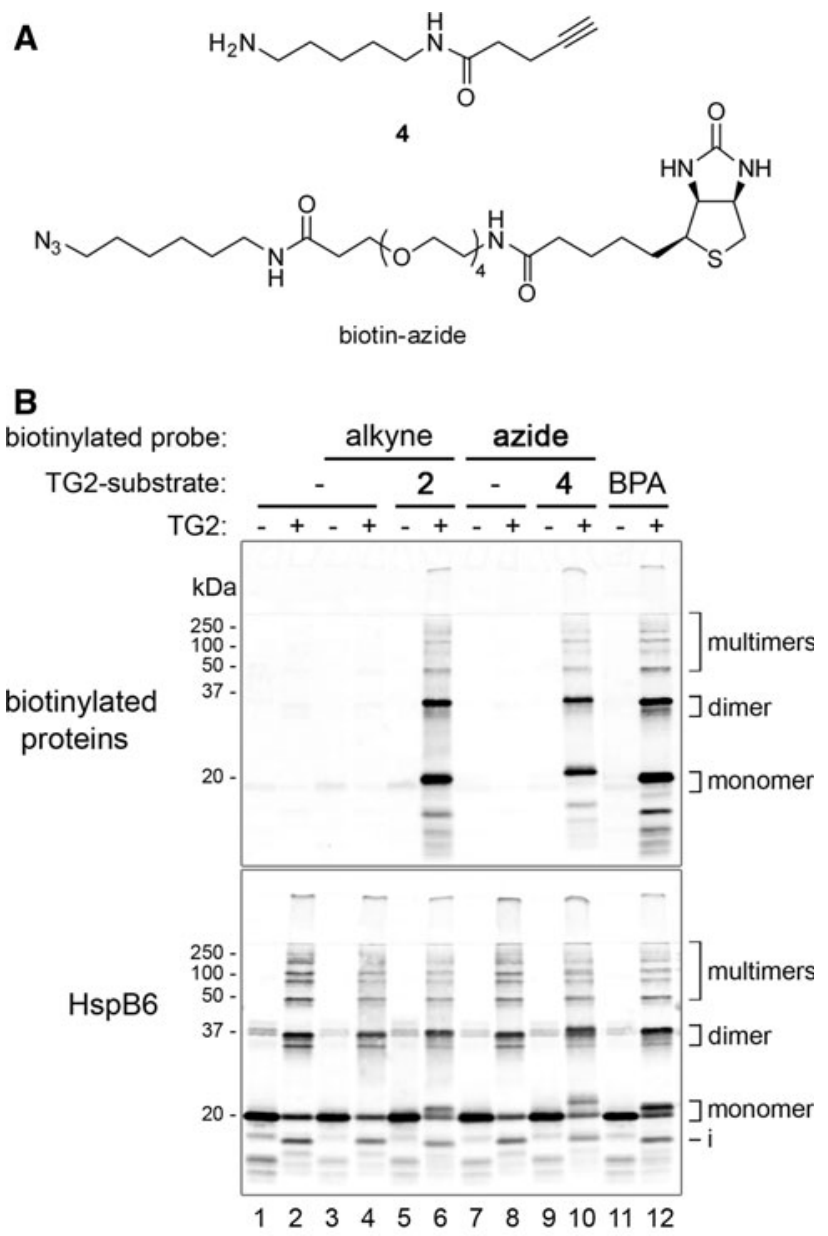

C

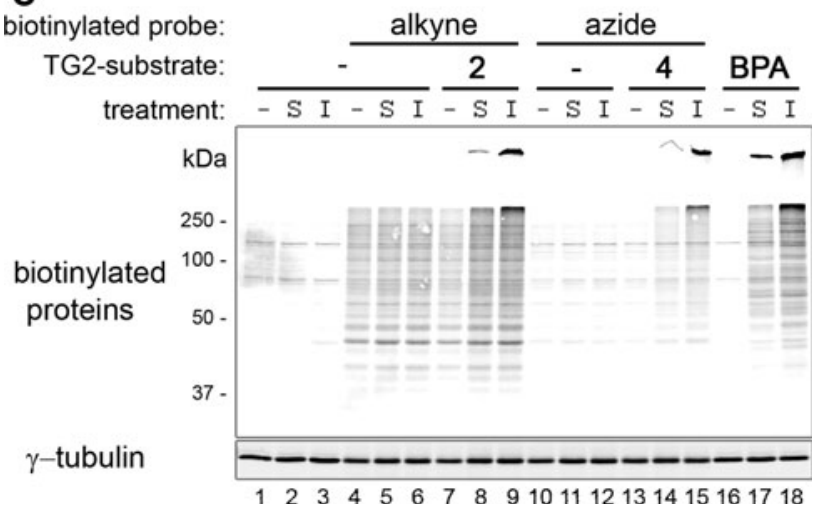

Fig. 6 Detection of TG2 activity with an alkyne-functionalized amine-donor substrate. a Structures of alkyne-containing substrate 4 and the corresponding biotinylated azide. b Substrates $\mathbf{2}$ and $\mathbf{4}$ were crosslinked by TG2 onto HspB6 and subsequently biotinylated via $\mathrm{CuAAC}$ using the appropriate probe. The analysis was performed as described for Fig. 3. c TG2 substrate proteins in HeLa cells were labeled with substrate $\mathbf{2}$ and $\mathbf{4}$ followed by biotinylation via the $\mathrm{CuAAC}$ using the appropriate probe. The analysis was performed as described for Fig. 4

This means that the azide- and alkyne-containing substrates not necessarily had to enter the cells in order to be crosslinked to proteins, although the scraping and ionophore 
treatment most likely only activate the cytosolic TG2. To confirm that the substrates can pass the cell membrane HspB6 was used, which is an excellent intracellular TG2substrate. HeLa cells were transfected with pIRES-HspB6 DNA and incubated for $2 \mathrm{~h}$ with substrates 1-4. BPA, which is a cell permeable substrate (Baumgartner et al. 2004; Zhang et al. 1998), was used as a positive control and the synthetic K-containing peptide (biotin-GNEPVK), which is a cell impermeable amine-donor substrate, as a negative control. TG2 activity was induced either by treatment with the $\mathrm{Ca}^{2+}$-ionophore $\mathrm{A} 23187$ or by scraping; only the latter disrupts the plasma membrane and thereby enables intracellular labeling by cell impermeable substrates. The cells were lysed and HspB6 was immunoprecipitated from the cell lysates, after which the incorporated azide- or alkyne-moieties were biotinylated via the $\mathrm{Cu}$ AAC. The biotinylated and the total amount of precipitated HspB6 were analyzed by western blotting (Fig. 7). When TG2 was activated by scraping, all substrates were crosslinked to HspB6 to varying extents (Fig. 7, lanes 4-6 and $8-10)$. However, when TG2 was activated by ionophoretreatment only substrates 1-4 as well as BPA showed a strong labeling intensity, in contrast to the cell impermeable K-peptide (Fig. 7). These results indicate that substrates 1-4 can indeed pass the cell membrane. This is in line with the cell penetrating properties observed for other small amine-donor substrates (Baumgartner et al. 2004; Lajemi et al. 1997; Zhang et al. 1998) and indicates that the azide or alkyne present in the substrates do not prevent entering cells.

\section{Fluorescent imaging of TG2-substrate proteins}

We next employed the alkyne-containing substrate $\mathbf{4}$ for fluorescent imaging of TG2 substrate proteins in cells.

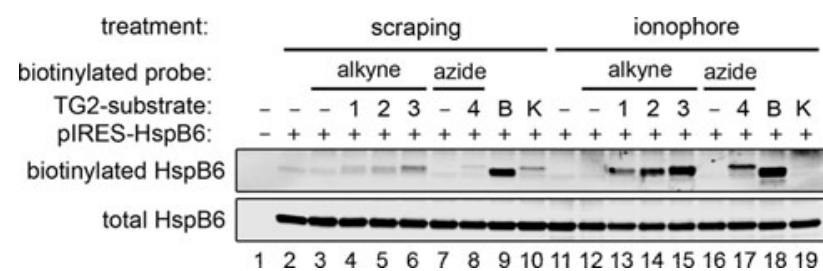

Fig. 7 Analysis of the membrane permeability of substrates 1-4. HeLa cells were transfected with pIRES-HspB6 and, after $24 \mathrm{~h}$, incubated with no substrate $(-)$, substrate $1,2,3,4$, the membrane permeable BPA or the membrane impermeable K-peptide. TG2 was activated by incubating with $\mathrm{Ca}^{2+}$-ionophore A23187, enabling labeling of HspB6 by cell permeable substrates only, or by scraping, enabling labeling of $\mathrm{HspB} 6$ regardless of the substrate permeability. HspB6 was isolated from the lysates of the treated cells by immunoprecipitation and biotinylated via CuAAC using the appropriate alkynyl and azido probes. The analysis was performed by western blot analysis using labeled streptavidin to detect biotinylated proteins (upper panel) or antibodies to HspB6 (lower panel)
For this experiment, we used the smooth muscle cell line Movas, which has a high extracellular TG2 activity (Van Geel et al., unpublished data). Movas cells were incubated simultaneously with substrate $\mathbf{4}$ and the fluorescently labeled amine-donor substrate FITC-cadaverine (Lajemi et al. 1997). After $24 \mathrm{~h}$, cells were fixed, labeled via $\mathrm{CuAAC}$ using an $\mathrm{Alexa}_{555}$-conjugated azido probe and analyzed by fluorescence microscopy. As a negative control, both substrates were omitted (Fig. 8). Cells treated with alkyne-containing substrate 4 , but not the control cells, showed specific labeling with the fluorescent azide of a subset of the Movas cells. This labeling completely colocalized with the incorporated FITC-cadaverine, which shows that TG2-substrate proteins can be visualized in cell cultures using click chemistry.

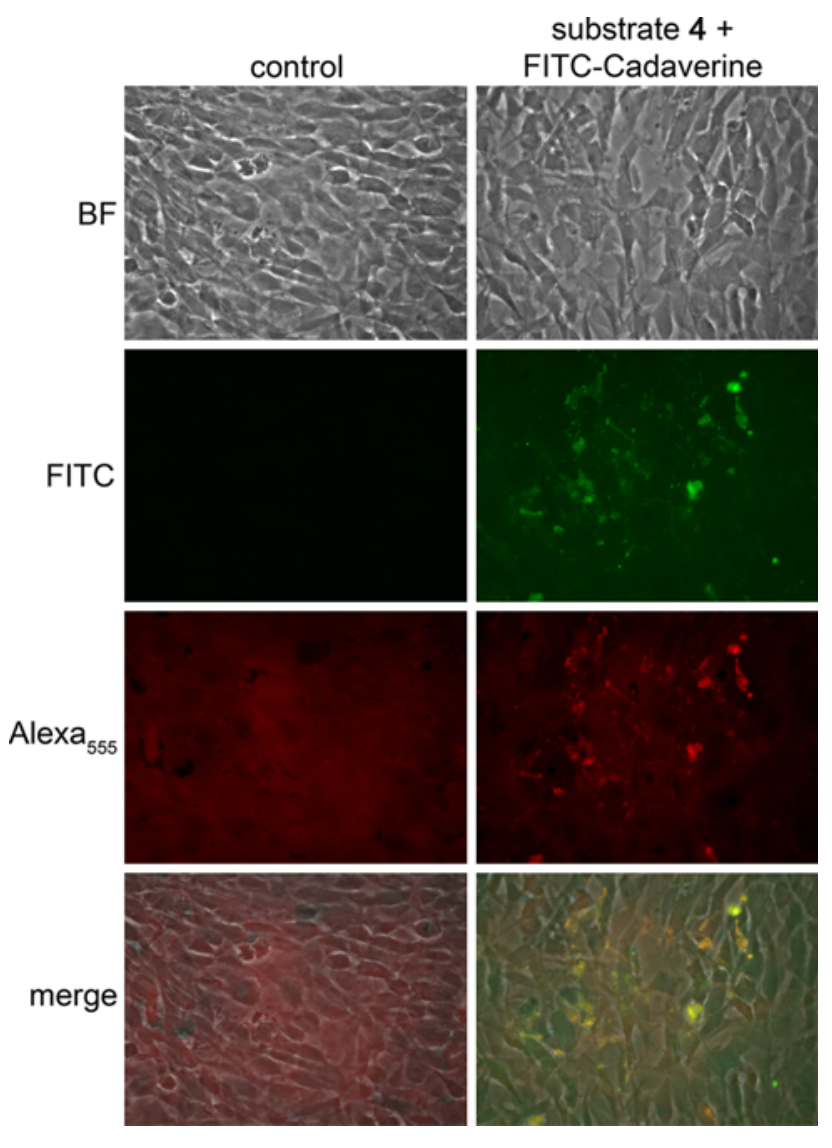

Fig. 8 Visualization of fluorescently labeled TG2 substrates in Movas cells. Movas cells were incubated for $24 \mathrm{~h}$ without substrate (left panel) or with azido substrate 4 together with FITC-cadaverine (right panel). Cells were fixed, stained with Alexa $\mathrm{a}_{55}$-azide for $1 \mathrm{~h}$ and subsequently analyzed by fluorescence microscopy for bright field (BF, first row), FITC-cadaverine (FITC, second row) and Alexa 555 -azide (Alexa ${ }_{555}$, third row). Overlays are composed of all three channels (merge, fourth row) 


\section{Conclusions}

In this study, we demonstrated that azide- and alkynecontaining pentylamines are efficiently crosslinked to amine-acceptor substrate proteins in a TG2-dependent manner. These tagged pentylamines are membrane permeable, allowing labeling of intracellular amine-acceptor substrate proteins in intact cells. After fixation or cell lysis, the introduced azide- or alkyne-handles can be labeled via CuAAC, allowing detection by western blotting or fluorescence microscopy. Under CuAAC conditions, the azido probe shows, compared to the alkynyl probe, a somewhat lower non-specific reactivity towards proteins and therefore, the former might be preferred when a high signalto-noise ratio is needed. Furthermore, SPAAC could be applied successfully to biotinylate azide-modified TG2 substrate proteins, thereby avoiding the need for toxic copper ions.

Overall, the click chemistry-based method may be an attractive alternative method for the detection of TG2 activity and/or substrates because of the advantage of the relatively small size of the amine-donor substrate and the introduction of a flexible labeling step after the crosslinking of the substrate, allowing differential labeling of cellular proteins. This new method may therefore help to shed more light on the role of TG2 in different cellular and/or pathological processes.

Acknowledgments Floris van Delft is kindly acknowledged for his help and advice and Erik Bakker for providing us with the Movas cell line. Part of this work was financially supported by the Netherlands Proteomics Centre, a program embedded in the Netherlands Genomics Initiative.

Open Access This article is distributed under the terms of the Creative Commons Attribution Noncommercial License which permits any noncommercial use, distribution, and reproduction in any medium, provided the original author(s) and source are credited.

\section{References}

Achyuthan KE, Greenberg CS (1987) Identification of a guanosine triphosphate-binding site on guinea-pig liver transglutaminase. Role of GTP and calcium-ions in modulating activity. J Biol Chem 262(4):1901-1906

Agard NJ, Prescher JA, Bertozzi CR (2004) A strain-promoted $[3+2]$ azide-alkyne cycloaddition for covalent modification of biomolecules in living systems. J Am Chem Soc 126(46):1504615047

Alea MP, Kitamura M, Martin G, Thomas V, Hitomi K, El Alaoui S (2009) Development of an isoenzyme-specific colorimetric assay for tissue transglutaminase 2 cross-linking activity. Anal Biochem 389(2):150-156

Baskin JM, Bertozzi CR (2007) Bioorthogonal click chemistry: covalent labeling in living systems. QSAR Comb Sci 26(11-12): 1211-1219
Baumgartner W, Golenhofen N, Weth A, Hiiragi T, Saint R, Griffin M, Drenckhahn D (2004) Role of transglutaminase 1 in stabilisation of intercellular junctions of the vascular endothelium. Histochem Cell Biol 122(1):17-25

Boros S, Ahrman E, Wunderink L, Kamps B, de Jong WW, Boelens WC, Emanuelsson CS (2006) Site-specific transamidation and deamidation of the small heat-shock protein Hsp20 by tissue transglutaminase. Proteins Struct Funct Bioinf 62(4):1044-1052

Boros S, Kamps B, Wunderink L, de Bruijn W, de Jong WW, Boelens WC (2004) Transglutaminase catalyzes differential crosslinking of small heat shock proteins and amyloid-beta. FEBS Lett 576(1-2):57-62

Chang PV, Prescher JA, Sletten EM, Baskin JM, Miller IA, Agard NJ, Lo A, Bertozzi CR (2010) Copper-free click chemistry in living animals. Proc Natl Acad Sci USA 107(5):1821-1826

Dafik L, Khosla C (2011) Dihydroisoxazole analogs for labeling and visualization of catalytically active transglutaminase 2 . Chem Biol 18(1):58-66

Debets MF, van Berkel SS, Schoffelen S, Rutjes F, van Hest JCM, van Delft FL (2010a) Aza-dibenzocyclooctynes for fast and efficient enzyme PEGylation via copper-free $(3+2)$ cycloaddition. Chem Commun 46(1):97-99

Debets MF, van der Doelen CW, Rutjes FP, van Delft FL (2010b) Azide: a unique dipole for metal-free bioorthogonal ligations. Chem Biochem 11(9):1168-1184

DeGraw AJ, Palsuledesai C, Ochocki JD, Dozier JK, Lenevich S, Rashidian M, Distefano MD (2010) Evaluation of alkynemodified isoprenoids as chemical reporters of protein prenylation. Chem Biol Drug Des 76(6):460-471

Dommerholt J, Schmidt S, Temming R, Hendriks LJA, Rutjes F, van Hest JCM, Lefeber DJ, Friedl P, van Delft FL (2010) Readily accessible bicyclononynes for bioorthogonal labeling and threedimensional imaging of living cells. Angew Chem Int Ed 49(49):9422-9425

Esposito C, Caputo I (2005) Mammalian transglutaminases, identification of substrates as a key to physiological function and physiopathological relevance. FEBS J 272(3):615-631

Fesus L, Piacentini M (2002) Transglutaminase 2: an enigmatic enzyme with diverse functions. Trends Biochem Sci 27(10):534-539

Folk JE (1983) Mechanism and basis for specificity of transglutaminase-catalyzed-epsilon-(gamma-glutamyl) lysine bond formation. Adv Enzymol Relat Areas Mol Biol 54:1-56

Goddard-Borger ED, Stick RV (2007) An efficient, inexpensive, and shelf-stable diazotransfer reagent: imidazole-1-sulfonyl azide hydrochloride. Org Lett 9(19):3797-3800

Griffin M, Casadio R, Bergamini CM (2002) Transglutaminases: nature's biological glues. Biochem J 368:377-396

Hasegawa G, Suwa M, Ichikawa Y, Ohtsuka T, Kumagai S, Kikuchi M, Sato Y, Saito Y (2003) A novel function of tissue-type transglutaminase: protein disulphide isomerase. Biochem $\mathrm{J}$ 373:793-803

Hong V, Presolski SI, Ma C, Finn MG (2009) Analysis and optimization of copper-catalyzed azide-alkyne cycloaddition for bioconjugation. Angew Chem Int Ed 48(52):9879-9883

Hsu TL, Hanson SR, Kishikawa K, Wang SK, Sawa M, Wong CH (2007) Alkynyl sugar analogs for the labeling and visualization of glycoconjugates in cells. Proc Natl Acad Sci USA 104(8): 2614-2619

Im MJ, Riek RP, Graham RM (1990) A novel guanine nucleotidebinding protein coupled to the alpha 1-adrenergic receptor, II. Purification, characterization, and reconstitution. J Biol Chem 265(31):18952-18960

Jeon JH, Kim CW, Shin DM, Kim KI, Cho SY, Kwon JC, Choi KH, Kang HS, Kim IG (2003) Differential incorporation of biotinylated polyamines by transglutaminase 2 . FEBS Lett $534(1-3)$ : 180-184 
Kolb HC, Finn MG, Sharpless KB (2001) Click chemistry: diverse chemical function from a few good reactions. Angew Chem Int Ed 40(11):2004-2021

Krapcho AP, Kuell CS (1990) Mono-protected diamines. N-tertbutoxycarbonyl-alpha, omega-alkanediamines from alpha, omega-alkanediamines. Synth Commun 20(16):2559-2564

Lai TS, Slaughter TF, Peoples KA, Hettasch JM, Greenberg CS (1998) Regulation of human tissue transglutaminase function by magnesium-nucleotide complexes, Identification of distinct binding sites for Mg-GTP and Mg-ATP. J Biol Chem 273(3): 1776-1781

Lajemi M, Demignot S, Borge L, ThenetGauci S, Adolphe M (1997) The use of fluoresceincadaverine for detecting amine acceptor protein substrates accessible to active transglutaminase in living cells. Histochem J 29(8):593-606

Laughlin ST, Baskin JM, Amacher SL, Bertozzi CR (2008) In vivo imaging of membrane-associated glycans in developing zebrafish. Science 320(5876):664-667

Lesort M, Tucholski J, Miller ML, Johnson GVW (2000) Tissue transglutaminase: a possible role in neurodegenerative diseases. Prog Neurobiol 61(5):439-463

Lutz JF (2008) Copper-free azide-alkyne cycloadditions: new insights and perspectives. Angew Chem Int Ed 47(12):2182-2184

McNeil PL, Kirchhausen T (2005) An emergency response team for membrane repair. Natl Rev Mol Cell Biol 6(6):499-505

Neef AB, Schultz C (2009) Selective fluorescence labeling of lipids in living cells. Angew Chem Int Ed 48(8):1498-1500

Nemes Z, Petrovski G, Fesus L (2005) Tools for the detection and quantitation of protein transglutamination. Anal Biochem 342(1): $1-10$

Ning XH, Guo J, Wolfert MA, Boons GJ (2008) Visualizing metabolically labeled glycoconjugates of living cells by copper-free and fast huisgen cycloadditions. Angew Chem Int Ed 47(12):2253-2255

Parameswaran KN, Cheng XF, Chen EC, Velasco PT, Wilson JH, Lorand L (1997) Hydrolysis of gamma:epsilon isopeptides by cytosolic transglutaminases and by coagulation factor XIII(a). J Biol Chem 272(15):10311-10317
Park D, Choi SS, Ha KS (2010) Transglutaminase 2: a multifunctional protein in multiple subcellular compartments. Amino Acids 39(3):619-631

Reif S, Lerner A (2004) Tissue transglutaminase-the key player in celiac disease: a review. Autoimmun Rev 3(1):40-45

Rostovtsev VV, Green LG, Fokin VV, Sharpless KB (2002) A stepwise Huisgen cycloaddition process: copper(I)-catalyzed regioselective "ligation" of azides and terminal alkynes. Angew Chem Int Ed 41(14):2596-2599

Samelak A, Sobieszczuk-Nowicka E, Legocka J (2010) Transglutaminases and their biological role. Postepy Biol Komorki 37(3):599-612

Schaertl S, Prime M, Wityak J, Dominguez C, Munoz-Sanjuan I, Pacifici RE, Courtney S, Scheel A, Macdonald D (2010) A profiling platform for the characterization of transglutaminase 2 (TG2) inhibitors. J Biomol Screening 15(5):478-487

Sletten EM, Bertozzi CR (2009) Bioorthogonal chemistry: fishing for selectivity in a sea of functionality. Angew Chem Int Ed 48(38):6974-6998

Speers AE, Cravatt BF (2004) Profiling enzyme activities in vivo using click chemistry methods. Chem Biol 11(4):535-546

Tornoe CW, Christensen C, Meldal M (2002) Peptidotriazoles on solid phase: [1, 2, 3]-triazoles by regiospecific copper(I)catalyzed 1, 3-dipolar cycloadditions of terminal alkynes to azides. J Org Chem 67(9):3057-3064

Verhaar R, Jongenelen CAM, Gerard M, Baekelandt V, Van Dam AM, Wilhelmus MMM, Drukarch B (2011) Blockade of enzyme activity inhibits tissue transglutaminase-mediated transamidation of alpha-synuclein in a cellular model of Parkinson's disease. Neurochem Int 58(7):785-793

Wilhelm B, Meinhardt A, Seitz J (1996) Transglutaminases: purification and activity assays. J Chromatogr B 684(1-2):163-177

Zhang JW, Lesort M, Guttmann RP, Johnson GVW (1998) Modulation of the in situ activity of tissue transglutaminase by calcium and GTP. J Biol Chem 273(4):2288-2295 